\title{
Genetic parameters for yield, fitness, and type traits in US Brown Swiss dairy cattle
}

\author{
K. D. Gibson ${ }^{1}$ and C. D. Dechow \\ Department of Animal Science, ThePennsylvania State University, University Park 16802
}

\begin{abstract}
The objective of this research was to evaluate heritabilities and genetic correlations among yield, fitness, and type traits for US Brown Swiss cattle born in 2000 and later. The data set used consisted of 108,633 first through fifth lactation records from 45,464 cows for yield, somatic cell score (SCS), days open, and productive life. Approximately half of the records had observations for 17 type traits and 41,074 had observations for milking speed. These data were analyzed using a series of 3 trait models. Heritability estimates of each trait were similar to previously reported values for both Holsteins, and Brown Swiss in other countries. Milk, fat, and protein yield had strong positive genetic correlations with productive life (0.67 to 0.71 ), whereas days open and SCS had strong negative correlations with productive life $(-0.60$ and -0.69 , respectively). Days open was more unfavorably correlated with dairy form (angularity) than with yield. The genetic correlation of udder depth and milk yield was unfavorable $(-0.40)$, whereas rear udder height (0.20) and width (0.48) were favorably correlated with milk yield. Udder depth had a favorable genetic correlation with SCS $(-0.26)$. Type traits with the strongest genetic correlations with productive life were fore udder attachment, mobility, and final score $(0.44,0.50$, and 0.57 , respectively). These updated genetic parameters will allow for improved genetic selection within the Brown Swiss breed.
\end{abstract}

Key words: yield, type, milking speed, mobility

\section{INTRODUCTION}

Worldwide, dairy cattle breeding programs have shifted their emphasis from primarily yield and type traits to a more balanced breeding objective that includes fitness traits (Miglior et al., 2005). Relationships among yield, type, and fitness traits have been well documented for Holstein cattle in the United States;

Received April 18, 2017

Accepted October 2, 2017.

${ }^{1}$ Corresponding author: kgibson@selectsires.com however, such is not the case for Brown Swiss cattle. Holsteins make up approximately $85 \%$ of the US dairy herd, whereas Brown Swiss represent less than $1 \%$. However, Brown Swiss cattle offer benefits from a cheese-making standpoint and were reported to yield $5 \%$ more cheese despite producing $9 \%$ less milk on a per-day basis (De Marchi et al., 2008). This is an attractive characteristic in a changing dairy market, where in the United States cheese production has doubled over the past 25 yr (Johnson and Lucey, 2006). The objective of this study was to estimate heritabilities and correlations among yield, fitness, and type traits using a population of Brown Swiss cows in the United States to update genetic parameters and facilitate progress for the breed.

\section{MATERIALS AND METHODS}

Data were from first- through fifth-lactation Brown Swiss cows in the United States born in 2000 or later from herds involved in DHI testing. There were 108,633 lactation records with data for at least 1 trait from 45,464 cows in 386 herds and 8,420 herd calving clusters. Herd calving clusters comprised cows that calved in the same herd in the same time period and were generated with the FASTCLUS procedure of SAS (version 9.4; SAS Institute, Cary, NC), with starting cluster seeds set to a 60-d window and a minimum of 10 cows per cluster required. Records for second and later lactations for all traits were kept only from cows that also had a first-lactation record in the data set to avoid selection bias. In total, 105,991 of the records had values for milk, fat, and protein yield, which were adjusted to 305-d mature equivalents, and 104,909 records had a lactation-average SCS value. The 2,642 records missing yield data were from cows that calved but then died or were culled early in lactation and before they had a $305-\mathrm{d}$ yield. These records were still considered for productive life evaluations. Productive life was available for 31,489 cows and was expressed as months in milk with the diminishing credits procedure as described by VanRaden et al. (2006). Days open records were confirmed by subsequent calvings, veterinary confirma- 
Table 1. Descriptive statistics of yield, fitness, and type traits ${ }^{1}$

\begin{tabular}{lcccccc}
\hline Trait & No. of records & No. of cows & Mean & SD & Minimum & Maximum \\
\hline MY (kg) & 105,991 & 45,423 & 9,882 & 213 & 1,964 & 24,081 \\
FY (kg) & 105,991 & 45,423 & 399 & 93 & 64 & 1,283 \\
PY (kg) & 105,991 & 45,423 & 328 & 70 & 70 & 748 \\
SCS & 104,909 & 45,088 & 2.76 & 1.3 & 0.15 & 9.58 \\
MS & 41,074 & 26,346 & 5.8 & 1.5 & 1 & 8 \\
DO & 83,343 & 37,982 & 149.9 & 68.5 & 25 & 250 \\
PL & 31,489 & 31,489 & 25.7 & 17.8 & 0.04 & 119 \\
STAT & 52,263 & 31,123 & 29.2 & 7.8 & 1 & 50 \\
STR & 52,262 & 31,123 & 26.0 & 7.6 & 3 & 45 \\
BD & 52,262 & 31,123 & 27.4 & 7.7 & 2 & 45 \\
RA & 52,259 & 31,122 & 24.3 & 7.2 & 5 & 45 \\
RW & 52,248 & 31,116 & 26.6 & 7.2 & 4 & 45 \\
DF & 52,257 & 31,123 & 27.9 & 8.1 & 1 & 50 \\
FA & 52,249 & 31,120 & 28.5 & 7.9 & 1 & 47 \\
RLS & 52,259 & 31,122 & 24.0 & 6.4 & 1 & 45 \\
RLR & 44,198 & 27,636 & 30.2 & 7.3 & 5 & 55 \\
MO & 35,442 & 22,414 & 84.1 & 4.3 & 50 & 5 \\
UD & 52,258 & 31,123 & 29.3 & 7.4 & 5 & 50 \\
FU & 52,251 & 31,121 & 27.5 & 8.1 & 2 & 50 \\
RUH & 52,246 & 31,115 & 28.2 & 7.3 & 2 & 49 \\
RUW & 52,240 & 31,112 & 28.8 & 7.7 & 1 & 3 \\
UC & 52,238 & 31,115 & 26.0 & 8.2 & 3 & 50 \\
TP & 52,254 & 31,122 & 25.8 & 7.5 & 4 & 2 \\
TL & 52,255 & 31,122 & 24.3 & 8.3 & 53 & 93 \\
FS & 52,262 & 31,125 & 84.2 & 3.3 & 53 \\
\hline
\end{tabular}

${ }^{1} \mathrm{MY}=$ milk yield; $\mathrm{FY}=$ fat yield; $\mathrm{PY}=$ protein yield; $\mathrm{MS}=$ milking speed; $\mathrm{DO}=$ days open; $\mathrm{PL}=$ productive life; STAT = stature; STR = strength; $\mathrm{BD}=$ body depth; $\mathrm{RA}=$ rump angle; $\mathrm{RW}=$ rump width; $\mathrm{DF}=$ dairy form; FA = foot angle; RLS = rear leg side view; RLR = rear leg rear view; $M O=$ mobility score; UD = udder depth; FU = fore udder attachment; RUH = rear udder height; RUW = rear udder width; $\mathrm{UC}=$ udder cleft; $\mathrm{TP}=$ teat placement; $\mathrm{TL}=$ teat length; $\mathrm{FS}=$ final score

tion of pregnancy, or culling for infertility. Days open values of less than 25 were recoded as missing, and days open greater than 250 were set to 250 , consistent with edits for national genetic evaluations of daughter pregnancy rate (VanRaden et al., 2004). Following this edit, there were 83,343 records that had a value for days open. Data for yield, SCS, productive life, and days open were provided by the Council on Dairy Cattle Breeding (Reynoldsburg, OH). In addition, producerassigned milking speed scores and classification scores were provided by the Brown Swiss Cattle Breeders' Association of the USA (Beloit, WI). There were 41,074 milking speed records on a scale of 1 (slow milking) to 8 (fast milking), approximately 52,250 records for 16 linear type traits scored on a scale of 1 to 50 , and a final classification score on a scale of 60 to 94 . There were also 35,442 mobility scores; these were assigned during type classification and range from 50 to 99 . A higher value is more desirable and indicates that the cow is able to move, stand up, and lie down and has structurally correct feet and legs. Number of records and cows, means, standard deviations, minimums, and maximums for each trait are summarized in Table 1. The final data set consisted of 45,464 first-lactation, 29,998 second-lactation, 18,327 third-lactation, 10,111 fourth-lactation, and 4,733 fifth-lactation records. The pedigree file included 127,401 animals, including 5,728 bulls with daughters that had records. Sire pedigrees were traced in the Council on Dairy Cattle Breeding database to 1960, whereas dam pedigrees were traced as far as the data would allow - generally back to 2000 .

These data were analyzed using a series of 3 trait models in ASREML (Gilmour et al., 2009). Three trait models were selected to reduce the total number of evaluations required when compared with 2-trait models and, at the same time, retain computational efficiency by not requiring estimation of an excessive number of parameters during a single analysis. In total, 142 evaluations were conducted so that each pair of traits was included together in at least 1 analysis. The model for the analyses was

$$
\mathrm{y}_{\mathrm{ijklm}}=\mu+\mathrm{L}_{\mathrm{i}}+\mathrm{Age}_{\mathrm{j}}+\mathrm{HCC}_{\mathrm{k}}+\mathrm{A}_{\mathrm{l}}+\mathrm{PE}_{\mathrm{m}}+\varepsilon_{\mathrm{ijklm}},
$$

where fixed effects were lactation ( $\mathrm{L} ; \mathrm{i}=1$ to 5$)$, age at calving class (Age; $\mathrm{j}=1$ to 94 classes, where there was a class for every month of age for animals 19 to 100 mo old, a class for every 2 mo of age for animals greater than 100 mo old, and a single class for animals greater than 125 mo old), and herd calving cluster (HCC; $\mathrm{k}=1$ to 8,420). Random effects were animal (A; $1=127,401)$, permanent environment ( $\mathrm{PE} ; \mathrm{m}=\mathrm{cow} 1$ to 45,464$)$, 
and residual $(\varepsilon)$. Permanent environment was not included for productive life. When multiple estimates of the same heritability or correlation were generated, the estimates were averaged across analyses.

\section{RESULTS}

Heritabilities, repeatabilities, genetic correlations, and phenotypic correlations among main traits of interest are shown in Table 2. Parameters on all traits are provided as supplemental information. Traits examined in Table 2 are milk, fat, and protein yields; SCS; milking speed; days open; productive life; udder depth; rear udder height; rear udder width; fore udder attachment; dairy form; stature; mobility; and final score. The heritability estimates of milk, fat, and protein yields were $0.30,0.20$, and 0.20 , respectively. Heritability estimates of SCS, milking speed, days open, and productive life were $0.12,0.26,0.03$, and 0.11 , respectively. The standard errors of heritability estimates were low, ranging from 0.0035 for days open to 0.0145 for milking speed. Genetic correlations between yield traits were strong and positive, ranging from 0.75 between milk and fat yields to 0.90 between milk and protein yields. Genetic correlations of productive life with days open and SCS were strong and negative $(-0.60$ and -0.69 , respectively), favoring cows with fewer days open and lower SCS. Genetic correlations of yield traits were slightly positive with days open $(0.15,0.18$, and 0.11 with milk, fat, and protein yields, respectively), suggesting that higher yield resulted in more days open. Relationships between yield and productive life were positive and strong, ranging from 0.63 with fat yield and 0.71 with protein yield.

The udder trait most unfavorably correlated with yield was udder depth; genetic correlations with milk, fat, and protein yields were $-0.40,-0.24$, and -0.37 , respectively. In addition, fore udder attachment was negatively correlated, although to a lesser extent than udder depth, with estimates ranging from -0.04 with fat yield to -0.21 with milk yield. These relationships indicate that shallower, more tightly attached udders held less milk. Rear udder height and rear udder width had moderately positive genetic correlations with yield, ranging from 0.19 between protein yield and rear udder height to 0.48 between milk yield and rear udder width. Relationships between SCS and rear udder height were near zero but favorable for fore udder attachment and udder depth ( -0.14 and -0.26 , respectively). Rear udder width was unfavorably correlated with SCS (0.18). Genetic correlations between milking speed and udder traits ranged from 0.09 with rear udder width to 0.37 with udder depth. Udder depth had a slightly favorable relationship with days open $(-0.19)$; cows with shallower udders also had fewer days open. Genetic correlations between days open and rear udder height and rear udder width were unfavorable $(0.32$ and 0.55 , respectively). Fore udder attachment had the strongest genetic correlation with productive life $(0.44)$, followed by rear udder width (0.40), udder depth (0.35), and rear udder height (0.33). These relationships were all favorable, with cows having more desirable udder conformation also having a longer productive life.

Dairy form, stature, mobility, and final score were also identified as key traits in this analysis. The heritability estimates of each trait were $0.19,0.42,0.11$, and 0.27 , respectively. Dairy form was positively correlated with all 3 yield traits, ranging from 0.31 with protein to 0.40 with milk, but unfavorably correlated with SCS (0.17) and generally unrelated to milking speed (0.10). Dairy form was unfavorably correlated with days open (0.52), indicating that more angular, sharper cows were susceptible to compromised fertility. The genetic correlation between dairy form and productive life was favorable yet small (0.12). Relationships between stature and yield were slightly positive, ranging from 0.11 with milk to 0.16 with protein yield, and were mostly unrelated to SCS, milking speed, and productive life. Stature was unfavorably correlated with days open (0.27), suggesting that taller cows also had compromised fertility. Mobility was more strongly related to yield traits than was stature, ranging from 0.26 to 0.27 . Additionally, mobility was more favorable with SCS (-0.14) and milking speed (0.31) although comparable in its relationship with days open (0.24). Mobility was positively correlated with productive life with an estimate of 0.50 , suggesting that cows with improved mobility were also able to remain in the herd for longer.

When examining relationships among the linear type traits, most of the estimates were positive between the udder traits. Udder depth and fore udder attachment were most related, with a genetic correlation of 0.76 , followed by rear udder height and rear udder width (0.51) and rear udder height and fore udder attachment (0.45). Dairy form was positively correlated with rear udder height and rear udder width, with estimates of 0.42 and 0.37 , respectively. There was a -0.28 genetic correlation between udder depth and dairy form, suggesting that more angular cows also had deeper udders. There was a positive genetic correlation between stature and dairy form (0.45) as well as rear udder height (0.21) and udder depth (0.18).

The genetic correlation of mobility and final score was 0.81 , and mobility was positively correlated with all other type traits, particularly rear udder height, rear udder width, and dairy form. The relationships of rear udder height and rear udder width with final score were 


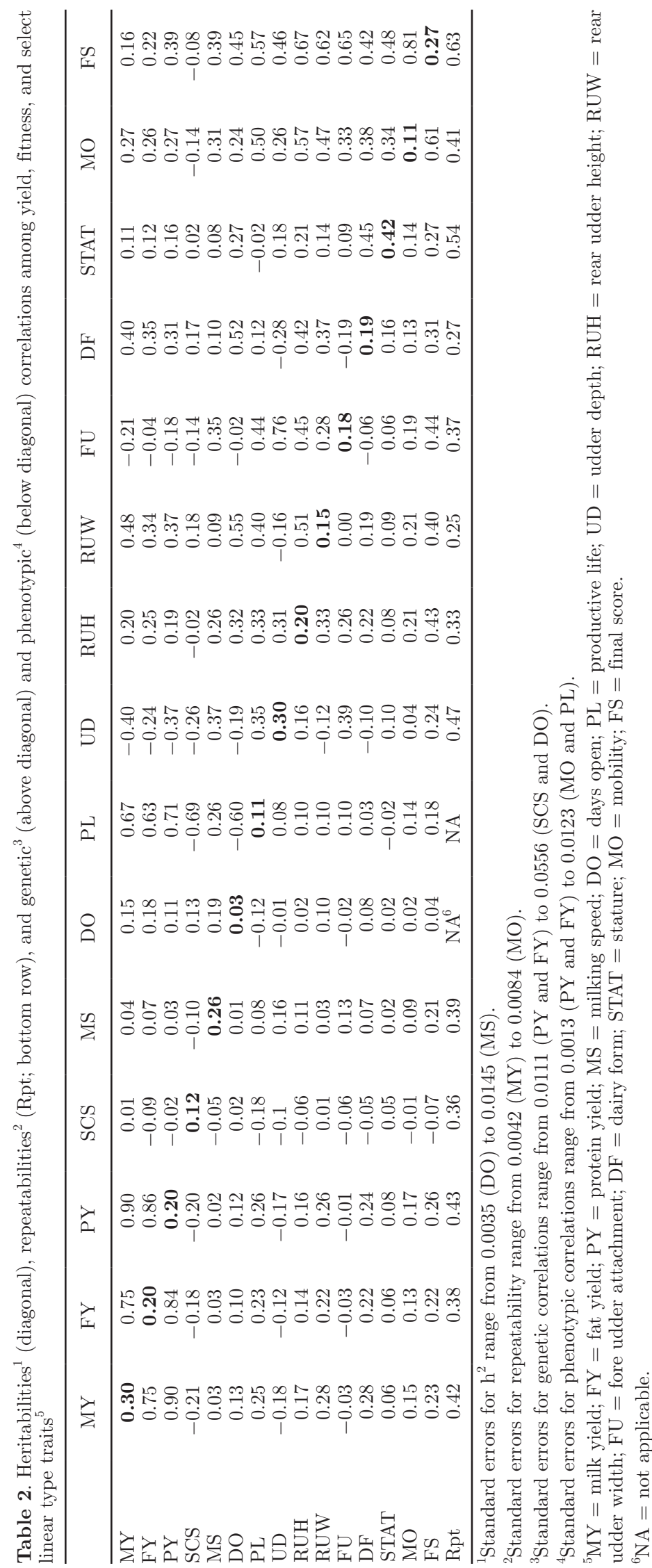


stronger than those for mobility and were 0.67 and 0.62 , respectively. Genetic correlations of final score with dairy form and stature were 0.42 and 0.48 , respectively. Therefore, cows receiving higher mobility scores and final scores were those that had more desirable udder conformation and that were taller and sharper.

\section{DISCUSSION}

Many of the heritability estimates in Brown Swiss were similar to reported values for Holsteins. Yield traits were moderately heritable, although slightly higher than sometimes reported for Holsteins (Schutz et al., 1990), and consistent with previous estimates in Italian Brown Swiss (Samoré et al., 2010). This is also reflected in US national genetic evaluations where milk, fat, and protein yield heritabilities are estimated to be 0.23 for Brown Swiss versus 0.20 for Holsteins (CDCB, 2017). Among yield traits, the strongest genetic correlation was observed between milk yield and protein yield, as seen in estimates assumed in CDCB evaluations and in the previously mentioned study of Italian Brown Swiss (Samoré et al., 2010). However, in the current study, the genetic correlation of milk yield with fat yield (0.90) was notably stronger than that seen in the aforementioned work in Holsteins (0.57-0.61). This is consistent with previous studies for Brown Swiss in Italy, which reported the genetic correlation of milk yield with fat yield as 0.79 (Samoré et al., 2010) and 0.85 (Santus et al., 1993).

A potential explanation of the stronger genetic correlation of milk yield and fat yield seen in Brown Swiss could be a breed difference in DGAT1 (Riquet et al., 1999; Grisart et al., 2002) variation. Marker associations for Holsteins demonstrate a strong effect on BTA 14 in the region of DGAT1 (CDCB, 2015a). There is no clear effect for Brown Swiss (CDCB, 2015b). If the same variants of DGAT1 are not present at the same frequency in Brown Swiss as seen in Holsteins, or if the variants have a different effect, then perhaps fat yield in Brown Swiss is more driven by milk yield.

In the current study, SCS had a relatively low heritability, consistent with previous findings for Holsteins (Samoré and Groen, 2006) and for Italian Brown Swiss (Samoré et al., 2010). The heritability estimate for productive life was also low and similar to heritability estimates in previous literature using the diminishing credit measure of productive life (VanRaden et al., 2006) and heritability estimate for unadjusted herd life in Brown Swiss in Switzerland (Vukašinović et al., 1995). The strong negative correlation between SCS and productive life suggests that cows with lower resistance to mastitis leave the herd more quickly. The near-zero genetic correlations between yield traits and
SCS in the current study were different than in some other literature, which reported that increased yield results in an elevated SCS in both Holsteins (Rupp and Boichard, 1999) and Brown Swiss (Samoré et al., 2010). Genetic correlations between yield traits and productive life were consistent with findings for Brown Swiss in Switzerland (Vukašinović et al., 1995) when herd life was unadjusted for yield, indicating that cows with higher yield were able to avoid voluntary culling.

Days open had the lowest heritability of any trait in the analysis, consistent with estimates of $<0.05$ in Holsteins (Dematawewa and Berger, 1998; Dechow et al., 2004) and an estimate of 0.06 in Italian Brown Swiss (Tiezzi et al., 2011). This suggests that fertility is no more heritable in Brown Swiss than in Holsteins. Correlation between days open and SCS was unfavorable, indicating that cows with compromised udder health were open for longer periods of time, as seen in Holsteins (Miller et al., 2001). The unfavorable relationship between yield and fertility was less antagonistic in the current study than reported for Holsteins (Dematawewa and Berger, 1998; Dechow et al., 2004) and Italian Brown Swiss (Tiezzi et al., 2011). Dairy form was more antagonistic with fertility than were yield traits. The antagonistic relationship between dairy form and fertility has been well documented in previous work (Dechow et al., 2004; Zink et al., 2011), with more angular cows being less fertile. Additionally, in the current study and in Zink et al. (2011), taller cows were also found to have increased days open.

Milking speed was also identified as a trait of interest in this analysis, as there is limited previous research available. It was found to be moderately heritable and very similar to the previous estimate of 0.22 , reported by Wiggans et al. (2007) using the same producer-assigned milking speed scoring system in US Brown Swiss. The near-zero correlations between yield traits and milking speed were consistent with those reported in Zwald et al. (2005). The current study also found near-zero correlations between SCS and milking speed. This was different from most previous literature (Boettcher et al., 1998; Rupp and Boichard, 1999; Zwald et al., 2005), which found an unfavorable relationship between milking speed and SCS in Holsteins. However, Wiggans et al. (2007) found a favorable correlation between milking speed and SCS in US Brown Swiss. The favorable correlation between milking speed and productive life indicates that faster milking cows either are able to more easily avoid involuntary culling or are favored by producers. There was also a favorable genetic correlation between milking speed and udder traits, particularly udder depth and fore udder attachment. Genetic correlations between yield traits and milking speed were near zero, suggesting that faster milking speeds can be 
attributed to improved udder conformation rather than lower yield.

Improved udder conformation was also associated with improved locomotion, as suggested by the favorable relationships between udder traits and mobility score. Mobility was also favorable with milk, fat, and protein yields, although to a lesser degree than correlations between mobility and yield PTA as estimated by Wright et al. (2013). The unfavorable genetic correlation between mobility and days open is in agreement with results for US Brown Swiss in Wright et al. (2013), where there was a negative genetic correlation between PTA for mobility score and PTA for daughter pregnancy rate (transformed from days open so that a higher number is more desirable). Despite its unfavorable relationship with fertility, mobility was positively associated with productive life in the current study and in Wright et al. (2013), suggesting that cows with improved locomotion avoided voluntary culling. The type trait most strongly correlated with mobility score was final classification score. This would suggest that higher scoring cows with more desirable conformation also have improved mobility. However, there is also the opportunity for evaluator bias. In a larger analysis of individual feet and leg traits (foot angle, rear leg side view, and rear leg rear view), relationships between yield and fitness traits with rear leg rear view were similar to those with mobility. However, the correlations of yield traits and fitness traits with the remaining 2 feet and leg traits were near zero.

\section{CONCLUSIONS}

Genetic parameters were estimated using a population of Brown Swiss in the United States born in the year 2000 and later. Yield was found to be moderately heritable and less antagonistic with SCS and fertility compared with previous results for Holsteins. Milk yield and fat yield were more strongly correlated in Brown Swiss than in Holsteins, possibly due to a difference in the effects of the DGAT1 gene. Cows with high yield, low SCS, fast milking speed, and few days open were favored and remained in the herd longer. Linear type traits most favorable with yield were rear udder width, rear udder height, and dairy form. However, these 3 traits were unfavorably correlated with days open. More angular cows had compromised fertility, as did cows with higher mobility scores and final classification scores, yet mobility score and final score were favorably correlated with productive life. Cows with shallower udders and stronger fore udder attachments were more resistant to mastitis and thus were more easily able to avoid culling. Rear udder height and rear udder width were less related to SCS but were favorable with pro- ductive life. The correlations among productive life and udder traits provided an analysis of which udder traits promoted longevity in the Brown Swiss breed and were used by the Brown Swiss Cattle Breeders' Association of the USA to develop a new udder composite formula.

\section{ACKNOWLEDGMENTS}

The authors greatly appreciate the Council on Dairy Cattle Breeding (Reynoldsburg, $\mathrm{OH}$ ) and the Brown Swiss Cattle Breeders' Association (Beloit, WI) for providing the data.

\section{REFERENCES}

Boettcher, P. J., J. C. Dekkers, and B. W. Kolstad. 1998. Development of an udder health index for sire selection based on somatic cell score, udder conformation, and milking speed. J. Dairy Sci. $81: 1157-1168$

CDCB (Council on Dairy Cattle Breeding). 2015a. SNP marker effects for Holstein fat. Accessed May 1, 2017. https://www.uscdcb.com/ Report_Data/Marker_Effects/marker_effects.cfm?Breed=HO\& Trait=Fat.

CDCB (Council on Dairy Cattle Breeding). 2015b. SNP marker effects for Brown Swiss fat. Accessed May 1, 2017. https://www.uscdcb .com/Report_Data/Marker_Effects/marker_effects.cfm?Breed= BS\&Trait $=$ Fat.

CDCB (Council on Dairy Cattle Breeding). 2017. Net merit as a measure of lifetime profit: 2017 revision. Accessed May 1, 2017. https://aipl.arsusda.gov/reference/nmcalc-2017.htm.

De Marchi, M., G. Bittante, R. Dal Zotto, C. Dalvit, and M. Cassandro. 2008. Effect of Holstein Friesian and Brown Swiss breeds on quality of milk and cheese. J. Dairy Sci. 91:4092-4102.

Dechow, C. D., G. W. Rogers, L. Klei, T. J. Lawlor, and P. M. VanRaden. 2004. Body condition scores and dairy form evaluations as indicators of days open in US Holsteins. J. Dairy Sci. 87:3534-3541.

Dematawewa, C. M., and P. J. Berger. 1998. Genetic and phenotypic parameters for 305-day yield, fertility, and survival in Holsteins. J. Dairy Sci. 81:2700-2709.

Gilmour, A. R., B. J. Gogel, B. R. Cullis, and R. Thompson. 2009. ASReml User Guide Release 3.0. VSN International Ltd., Hemel Hempstead, UK. www.vsni.co.uk.

Grisart, B., W. Coppieters, F. Farnir, L. Karim, C. Ford, P. Berzi, N. Cambisano, M. Mni, S. Reid, P. Simon, R. Spelman, M. Georges, and R. Snell. 2002. Positional candidate cloning of a QTL in dairy cattle: Identification of a missense mutation in the bovine DGAT1 gene with major effect on milk yield and composition. Genome Res. 12:222-231.

Johnson, M. E., and J. A. Lucey. 2006. Major technological advances and trends in cheese. J. Dairy Sci. 89:1174-1178.

Miglior, F., B. L. Muir, and B. J. Van Doormaal. 2005. Select indices in Holstein cattle of various countries. J. Dairy Sci. 88:1255-1263.

Miller, R. H., J. S. Clay, and H. D. Norman. 2001. Relationship of somatic cell score with fertility measures. J. Dairy Sci. 84:2543-2548.

Riquet, J., W. Coppieters, N. Cambisano, J. J. Arranz, P. Berzi, S. K. Davis, B. Grisart, F. Farnir, L. Karim, M. Mni, P. Simon, J. F. Taylor, P. Vanmanshoven, D. Wagenaar, J. E. Womack, and M. Georges. 1999. Fine-mapping of quantitative trait loci by identity by descent in outbred populations: Application to milk production in dairy cattle. Proc. Natl. Acad. Sci. USA 96:9252-9257.

Rupp, R., and D. Boichard. 1999. Genetic parameters for clinical mastitis, somatic cell score, production, udder type traits, and milking ease in first lactation Holsteins. J. Dairy Sci. 82:2198-2204.

Samoré, A. B., and A. F. Groen. 2006. Proposal of an udder health genetic index for the Italian Holstein Friesian based on first lactation data. Ital. J. Anim. Sci. 5:359-370. 
Samoré, A. B., R. Rizzi, A. Rossoni, and A. Bagnato. 2010. Genetic parameters for functional longevity, type traits, SCS, milk flow and production in the Italian Brown Swiss. Ital. J. Anim. Sci. 9:145-152.

Santus, E. C., R. W. Everett, R. L. Quaas, and D. M. Galton. 1993 Genetic parameters of Italian brown Swiss for levels of herd yield. J. Dairy Sci. 76:3594-3600.

Schutz, M. M., L. B. Hansen, G. R. Steuernagel, J. K. Reneau, and A. L. Kuck. 1990. Genetic parameters for somatic cells, protein, and fat in milk of Holsteins. J. Dairy Sci. 73:494-502.

Tiezzi, F., C. Maltecca, M. Penasa, A. Cecchinato, Y. M. Change, and G. Bittante. 2011. Genetic analysis of fertility in the Italian Brown Swiss population using different models and trait definitions. J. Dairy Sci. 94:6162-6172.

VanRaden, P. M., C. M. B. Dematawewa, R. E. Pearson, and M. E. Tooker. 2006. Productive life including all lactations and longer lactations with diminishing credits. J. Dairy Sci. 89:3213-3220.

VanRaden, P. M., A. H. Sanders, M. E. Tooker, R. H. Miller, H. D. Norman, M. T. Kuhn, and G. R. Wiggans. 2004. Develop- ment of a national genetic evaluation for cow fertility. J. Dairy Sci. 87:2285-2292.

Vukašinović, N., J. Moll, and N. Künzi. 1995. Genetic relationships among longevity, milk production, and type traits in Swiss Brown cattle. Livest. Prod. Sci. 41:11-18.

Wiggans, G. R., L. L. M. Thornton, R. R. Neitzel, and N. Gengler. 2007. Short communication: Genetic evaluation of milking speed for Brown Swiss dairy cattle in the United States. J. Dairy Sci. 90:1021-1023.

Wright, J. R., G. R. Wiggans, C. J. Muenzenberger, and R. R. Neitzel. 2013. Short communication: Genetic evaluation of mobility for Brown Swiss dairy cattle. J. Dairy Sci. 96:2657-2660.

Zink, V., M. Štípková, and J. Lassen. 2011. Genetic parameters for female fertility, locomotion, body condition score, and linear type traits in Czech Holstein cattle. J. Dairy Sci. 94:5176-5182.

Zwald, N. R., K. A. Weigel, Y. M. Chang, R. D. Welper, and J. S. Clay. 2005. Genetic evaluation of dairy sires for milking duration using electronically recorded milking times of their daughters. J. Dairy Sci. 88:1192-1198. 